\title{
Mahdollistuuko Parkinsonia sairastavan turvallinen ja omatoiminen kotikuntoutus? Katsaus suomalaisiin kuntoutuskäytäntöihin
}

\author{
Heli Vaartio-Rajalin, Anu Salpakoski, Hanna Hintikka
}

Suomessa noin 20 prosenttia väestöstä on yli 65-vuotiaita. Yli puolella heistä on jokin krooninen toimintakykyä ja elämänlaatua heikentävä sairaus, joka edellyttää säännöllistä kuntoutusta ja sopeutumisvalmennusta. Yksi tällainen on Parkinsonin tauti, jota sairastaa Suomessa noin 10000 - 12000 henkilöä; uusia diagnooseja tehdään noin 750 vuodessa. Tämä hitaasti etenevä neurologinen sairaus aiheuttaa ongelmia liikkumisessa, puhumisessa, nielemisessä, ulostamisessa, kognitiossa, mielialassa sekä sosiaalisessa aktiivisuudessa (Suomen Parkinsonliitto 2018). Kroonisessa sairaudessa kuntoutuksen tulos ei ole pysyvä, joten sopeutumisvalmennus- ja kuntoutuskurssien lisäksi tarvitaan säännöllistä, lähikontaktista riippumatonta kotikuntoutusta, joka auttaa yksilöä säilyttämään tai kehittämään toimintakykyään ja sopeutumaan erilaisiin tilanteisiin, kuten covid-19pandemiaan.

Sosiaali- ja terveysministeriö julkaisi hiljattain (2020) kuntoutuksen uudistamisen toimintasuunnitelman vuosille 2020-2022. Siinä ehdotetaan toiminta- ja työkyvyn arvioinnin perustaksi Maailman terveysjärjestö WHO:n ICF-viitekehystä (International Classification of Functioning, Disability and Health). ICFviitekehys tarkastelee toimintakykyä terveyden näkökulmasta, keskittyen pääasiallisesti terveydentilan häiriöön tai tautiin liittyvien ongel- mien kuvaukseen. Koska kotiin tuotavat palvelut ovat oleellinen osa kuntoutumista ja toimintakyvyn tukemista, toimintasuunnitelmassa nousevat esiin kotikuntoutuksen kehittäminen sekä etäkuntoutuksen ja digitaalisten palveluiden hyödyntäminen kotona asumisen tukena. Lisäksi suunnitelmassa ehdotetaan, että kotikuntoutuksessa tulisi ottaa vuonna 2023 käyttöön RAI-arviointimittaristo asiakkaan palvelutarpeen arviointiin ja kuntoutus- tai palvelusuunnitelman laatimiseen, huomioiden iäkkäiden omaishoitajat. Toimintasuunnitelmasta on siis löydettävissä pyrkimystä yhdenmukaiseen toimintakyvyn arviointiin tietystä viitekehyksestä katsottuna, yhdenmukaiseen arviointimittariston hyödyntämiseen sekä kuntoutuksen fokuksen siirtymiseen laitoksista etä- ja kotikuntoutukseen. ICF-viitekehys ei sellaisenaan kuitenkaan kata kaikkia kohderyhmän toimintakyvyn haasteita: toimintavajaukset kehittyvät vaihe vaiheelta, jolloin myös kuntouttamisessa tulisi huomioida yhden ominaisuuden kuntouttamisen sijaan erilaiset toimintavajaukset ja niiden vaikutukset toisiinsa. ICF ei myöskään huomioi kuntoutujan intressejä eikä sitä, millaiset mahdollisuudet hänellä on vaikuttaa toimintakykyynsä ja kuntoutumiseen omassa arkiympäristössään (Järvikoski ym. 2015; Scobbie \& Dixon 2015). 


\section{Tiedonkeruu}

Tässä katsauksessa kootaan yhteen tietoa eri palveluntuottajien järjestämistä sopeutumisvalmennus- ja kuntoutuskursseista Parkinsonin tautia sairastaville Suomessa. Analyysi on jatkumoa jo julkaistuun kartoittavaan katsaukseen (Vaartio-Rajalin ym. 2019) ja kehittämis- ja pilotointiraporttiin (Vaartio-Rajalin ym. 2020). Tämän katsauksen tiedonkeruun taustalla ovat Suomalainen Käypä hoito -suositus sekä eurooppalaiset Parkinson-fysioterapian, puheterapian, toimintaterapian ja ravitsemuksen suositukset (Kalf ym. 2011; Sturkenboom ym. 2011; van Asseldonk ym. 2012; Keus ym. 2014; Käypä hoito -suositus 2019). Näissä dokumenteissa toistuvat aihealueet ja teemat nostettiin tiedonkeruun kohteiksi pyrkimyksenä saada näkyviin nykytietämys Parkinsonin taudin kuntoutuksesta. Tutkimustietoa haettiin eri tietokannoista (Pubmed, CINAHL, PEDro, Medline ja Cochrane) syksyllä 2020. Lisäksi tietoa kerättiin Parkinsonin taudin hoitoketjuista ja kuntoutuskurssitoiminnasta Kelan, Parkinsonliiton ja sairaanhoitopiirien verkkosivuilta sekä näiden tuottamista materiaaleista. Parkinsonliiton kurssitoimintatietoa täydennettiin lisäksi haastattelemalla liiton suunnittelijaa. Kerättyä tietoa tarkastellaan suhteessa tutkimusnäyttöön, eurooppalaisiin ja suomalaisiin Parkinson-kuntoutussuosituksiin, moniammatillisuuteen ja asiakaskeskeisyyteen sekä omatoimisen kuntoutumisen ideaan kotona laitoskuntoutuksen jaksojen välillä. Katsauksessa pohditaan, missä määrin kuntoutuspalvelut mahdollistavat kuntoutujan kotona tapahtuvaa, turvallista omatoimista kuntoutumista.

\section{Katsauksen viitekehys}

Eurooppalainen Parkinsonin taudin kuntoutussuositus jakautuu neljään osaan: fysioterapia, toimintaterapia, puheterapia sekä ravitsemus (Kalf ym. 2011; Sturkenboom ym. 2011; van
Asseldonk ym. 2012; Keus ym. 2014). Nämä suositukset ovat ensimmäiset, jotka kuvaavat puheterapian ja toimintaterapian parhaita kuntoutuskäytäntöjä ja kattavat arvioinnit ja interventiot. Tässä katsauksessa keskitytään pääasiallisesti fysioterapiasuositukseen. Se on suosituksista ainoana laadittu laajana kansainvälisenä yhteistyönä, jossa myös Suomi on ollut mukana (Keus ym. 2014). Fysioterapiasuosituksessa kuntoutumisen osa-alueet ovat käveleminen, tasapaino, siirtymiset, fyysinen kunto ja muut (liikestrategiat, elämänlaatu, toimintakyvyn itsearvioitu vaikutus arkeen). Suosituksessa kehotetaan käyttämään ICF-luokitusta, joka koostuu toimintakyvystä ja toimintarajoitteista (ruumis/keho sekä suoritukset ja osallistuminen) sekä kontekstuaalisista tekijöistä, joihin kuuluvat ympäristötekijät (välittömät ja yleiset) sekä yksilötekijät (World Health Organization 2001). Nämä tekijät huomioidaan hyvin myös puheterapia- ja toimintaterapiasuosituksissa, joissa hyvä hoito perustuu hoitajan ja asiakkaan väliseen kumppanuuteen sekä moniammatillisuuteen ja terapian integrointiin osaksi arkea. Kuntoutuksessa muutoksen kohteina ovat potilas, toiminta, fyysinen ympäristö ja hoitaja sekä sosiaalinen ympäristö yksilöllisten tarpeiden, toivottavan toiminnan sekä ympäristön mukaan. Suositusten mukaan ICF voi toimia perustana kuntoutussuunnitelmille, jos se yhdistetään muutosprosessiin ja tavoitteenasetteluun, esimerkiksi motivoitumiseen, käyttäytymisen muutoksiin tai valtaistumiseen eli sosiokognitiivisen teoriaan Scobbien ja Dicksonin (2015) mukaan (Järvikoski ym. 2015, 27).

Käypä hoito -suositukset ovat Suomalaisen Lääkäriseura Duodecimin yhdessä erikoislääkäriyhdistysten kanssa kokoamia eri sairauksien diagnostiikkaan ja hoitoon liittyviä suosituksia. Parkinsonin taudin Käypä hoito -suositus esittää näyttöön perustuvan suosituksen diagnostiikasta, hoidon aiheista, hoitomenetelmien valinnasta, lääkkeiden käytöstä ja kuntoutuksesta. Suosituksen tavoitteena on yhtenäistää hoitokäytäntöjä. Suosituksessa Parkinsonin taudin kuntoutus (Käypä hoito -suositus 2019) on 
jaettu osiin: 1) fysio-/toimintaterapia ja neuropsykologinen kuntoutus, 2) kävelyn parantaminen, 3) tasapainon parantaminen ja kaatumisten ehkäisy, 4) päivittäisistä toimista suoriutuminen, 5) puheterapia, 6) perusterveydenhuollon osuus diagnostiikassa ja seurannassa, 7) laitospotilaiden hoito, 8) palliatiivinen hoito ja 9) potilasinformaatio. Suosituksissa sopeutumisvalmennuksen katsotaan olevan osa kuntoutusta. Suosituksen laatinut työryhmä toteaa, että Parkinsonin taudin kuntoutuksen tulisi kohdistua toimintakyvyn kannalta keskeiseen ongelmaan ja sen tulisi lähteä kuntoutujan tarpeesta. Keskiössä on omatoiminen säännöllinen liikunta ja kunnon ylläpito tai parantaminen ja siihen motivointi. Kuntoutusta suunniteltaessa huomioidaan, että kuntoutuja ja omainen voivat sitoutua sen toteuttamiseen, ja arviointi tehdään säännöllisesti esimerkiksi vuosittain.

Moniammatillisuudella tarkoitetaan sosiaali- ja terveyspalveluissa yleensä sitä, että eri ammattien ja tieteenalojen edustajat toimivat yhdessä asiakkaan tai potilaan parhaan mahdollisen hoidon takaamiseksi, jakaen erityisosaamisensa ja ammatillisen vastuun (Petri 2010). Moniammatillisuutta voidaan hyödyntää toisaalta myös kehittämis- ja tutkimushankkeissa (Brewster ym. 2019).

Asiakaskeskeisyyttä sosiaali- ja terveyspalvelujärjestelmässä voidaan tarkastella eri tasoilla (Lemetti ym. 2019). Organisaatiotasolla asiakaskeskeisyydellä tarkoitetaan yleensä sitä, että suunnittelun ja toiminnan keskeisenä lähtökohtana on asiakkaan kulku ja hoitopolku organisaatiossa (Suhonen 2018). Asiakasryhmäkohtaisesti se tarkoittaa sitä, miten tiettyjen terveysongelmien ja sairauksien hoitoon annetut Käypä hoito -suositukset toteutuvat potilasryhmittäin (Jokstad ym. 2019). Yksilötasolla asiakaskeskeisyys puolestaan liittyy siihen, miten kukin palvelun käyttäjä arvioi toteutunutta hoitoa omalla kohdallaan (Suhonen 2018).

Omatoimisella kuntoutumisella tarkoitetaan tässä katsauksessa kotona omaehtoisesti tai etäohjatusti tapahtuvaa fyysisen, psyykkisen ja sosiaalisen toimintakyvyn säilyttämiseen tai lisäämiseen tähtäävää tavoitteellista toimintaa.

\section{Parkinsonin taudin kuntoutus Suomessa}

Parkinsonin tautia sairastavien hoitopolkujen kuvauksia julkisessa terveydenhuollossa löytyi avoimissa verkoissa vain kaksi: Pohjois-Pohjanmaan sairaanhoitopiirissä (Oulun yliopistollinen sairaala) sekä Etelä-Savon sosiaali- ja terveyspalvelujen kuntayhtymässä (Essote). Saattaa olla, että hoitopolkuja on enemmänkin, mutta mikäli niitä on vain toimijoiden sisäisissä verkoissa, ei niiden voida olettaa edistävän asiakaskeskeisyyttä. Oulun mallissa hoitopolku on kuvattu organisatorisen asiakaskeskeisyyden näkökulmasta (perusterveydenhuolto/erikoissairaanhoito) eli sen mukaan, missä hoito ja kuntoutus tapahtuu. Hoitopolku pohjautuu kotimaiseen Käypä hoito -suositukseen ja on hyvin lääketieteellisesti lähestyvä, nostaen esiin eri oireiden ja liitännäissairauksien tunnistamisen ja hoidon. Sopeutumisvalmennuksen katsotaan olevan osa kuntoutusta, vaikka kuntoutumisen osa-alueet eivät juurikaan nouse esille fokuksen ollessa fyysisessä toimintakyvyssä. Lähiomaisten osuutta kuntoutuksessa tai kotikuntoutusta ei eritellä, ei myöskään kuntoutustulosten arviointitapaa tai -ajankohtaa. Hoitopolusta ei suoraan käy ilmi, vastaako kuntoutustarpeen arvioinnista perusterveydenhuolto vai erikoissairaanhoito.

Essoten hoitopolussa on hyödynnetty Parkinsonia sairastaville moniammatillisena yhteistyönä kehitettyä mallia. Hoitopolku on kuvattu siitä näkökulmasta, mitä palveluja katsotaan tarpeelliseksi taudin eri vaiheissa, eli hoitopolku vaikuttaa asiakasryhmäkeskeiseltä. Taudin varhais-, keski- ja edenneessä vaiheessa esiin nostetaan kronologisesti ensitietopäivät, sopeutumisvalmennus, sairaanhoitajan ja neurologin tapaamiset, neurologisen kuntoutusosaston toimet ja muu moniammatillinen tuki, kuntoutusjaksot ja terapiat (fysio-, toimintaja puheterapia, neuropsykologinen kuntoutus). 
Hoitopolku vaikuttaa holistiselta ja moniammatilliselta alusta alkaen. Koko sairauden ajan huomioidaan potilaan sekä läheisen voimavarat, ja moniammatillinen tiimi arvioi potilasta koko ajan, vaikkakaan arviointimittareita ei ole eritelty. Vaikuuttaa siltä, että hoitopolku pohjautuu eurooppalaiseen Parkinsonin taudin kuntoutussuositukseen ja että sen yksi tavoite on omatoimisen kuntoutumisen mahdollistaminen.

Kelan kuntoutuskurssit perustuvat yleensä kolmivuotiseen sopimuskauteen. Sopimuskausien muuttuessa voi tapahtua muutoksia muun muassa kurssien nimissä, kohderyhmissä ja rakenteessa. Parkinsonia sairastavien kurssit ovat muuttuneet sopeutumisvalmennus- ja kuntoutuskursseista kuntoutuskursseiksi. Kuntoutukseen osallistuva työryhmä on moniammatillinen. Siihen kuuluvat neurologi, sairaanhoitaja, fysioterapeutti ja psykologi sekä heidän lisäkseen erityistyöntekijän ominaisuudessa sosiaalityöntekijä tai sosionomi, toimintaterapeutti, ravitsemusterapeutti, seksuaalineuvoja/-terapeutti tai uroterapeutti ja puheterapeutti. Musiikkiterapeutti ja liikunnanohjaaja ovat voimassa olevalla sopimuskaudella jääneet pois kuntoutukseen osallistuvasta henkilöstöstä. Lisäksi tarkoista kohderyhmää määrittävistä tekijöistä on luovuttu. Keskeisin muutos kohderyhmän määrittelyssä on kuntoutujan iän liittäminen sairauden vaiheeseen: iän mukainen jako on alle ja yli 68-vuotiaat. Aiemmin vain sairauden vaihe (hiljattain eli alle viisi vuotta sitten sairastuneet ja pidempään sairastaneet) määritti, mille kurssille kuntoutuja suunnataan. Tämä muutos on selkeästi askel asiakaskeskeisempään suuntaan asiakasryhmä- ja yksilötasolla. Kuntoutujien ryhmäkoko on pienentynyt voimassa olevalla sopimuskaudella kymmenestä kuntoutujasta ja heidän läheisestään kahdeksaan kuntoutujaan ja heidän läheiseensä. Kursseilla asetetaan tavoitteet kuntoutusprosessin ajalle. Kelan palvelukuvauksessa on määritelty käsiteltäviä teemoja, joiden sisältä on mahdollista löytää tässä analyysissä kuvattuja kuntoutumisen osa-alueita, mutta niitä ei ole yksilöity tarkemmin. Kurssien sisällön toteutus voi poiketa eri palveluntuottajilla. Keskeinen tavoite näyttää kuitenkin olevan se, että Parkinsonia sairastava oppii itse vaikuttamaan omaan toiminta- ja/tai työkykyynsä. Kuntoutuja ja läheinen ovat kurssilla aktiivisessa roolissa. Tavoitteena on myös löytää kuntoutujille omatoimisia keinoja sopeutua sairauteen, vahvistaa voimavaroja ja elämänhallintaa sekä tukea näin mahdollisimman täysipainoisen arjen sujumista. Kursseilla pyritään erityisesti asettamaan kotiympäristöön ja arkeen suuntautuvia tavoitteita, mikäli kuntoutuja kokee ne mielekkäiksi ja tärkeiksi itselleen.

Tällaiset kurssisisällöt ja tavoitteenasettelut antavat aihetta olettaa, että toimintakykyluokitusta on täydennetty sosiokognitiivisella viitekehyksellä ja että kurssien yksi tavoite on omatoimisen kuntoutumisen mahdollistaminen. Tätä oletusta tukee myös se, että nykyisin yksilötapaamisia on aiempaa huomattavasti enemmän ja arviointia toteutetaan lähinnä laitoskuntoutusjaksojen välissä toteutettavien kahden yhteydenoton ja 2-4 koko kuntoutusprosessin jälkeisen seurantayhteydenoton tiimoilta. Kelan määrittäminä pakollisina mittareina (Kansaneläkelaitos 2020) ovat WHO:n elämänlaatumittari whoqol-brief (World Health Organization 1998), mielialakysely BDI21 (Beck ym. 1961), omat tavoitteet GASmenetelmällä (Terveysportti n.d.) ja työkykykysymykset, jos kuntoutuja on työssä, opiskelemassa tai palaamassa työelämään. Vapaaehtoisena toimintakykytestinä on TUG-testi (Mathias ym. 1986). Mittareihin vastaa kuntoutuja, joten toimintatapa on asiakaskeskeinen myös yksilötasolla. Kelan kuntoutuskurssien voidaan olettaa perustuvan eurooppalaisiin kuntoutussuosituksiin.

Parkinsonliiton kuntoutuskurssitoiminta on suunnattu liikehäiriösairauksia sairastaville ja heidän läheisilleen. Osa kurssitoiminnasta on tarkoitettu suoraan Parkinsonia sairastaville ja osa kaikille liikehäiriösairauksia sairastaville. Kohderyhmät Parkinsonin kursseilla on jaoteltu sairauden keston sekä kurssimuodon mukai- 
sesti: alle kolme vuotta sairastaneille avokurssit, 3-7 vuotta sairastaneille verkko- tai avokurssit ja puheongelmaisille oma kurssi. Vain pidempään sairastaneille on laitoskurssi. Tämä kertoo kurssien asiakaskeskeisyydestä ryhmätasolla. Toisaalta sairauden kesto ja vaiheet ovat jossain määrin yhtenevät, mutta koska tauti etenee yksilöllisesti, taudin vaiheessa voi olla eroa, vaikka sairaushistoria olisikin yhtä pitkä. Teemallisten kurssien sisällöt muodostuvat tutkitusta tiedosta, kohderyhmän hyvinvointia ja toimintakykyä tukevista asioista, sopeutumisen tukemisesta, voimavarojen löytämisestä, itsehoitoon motivoimisesta sekä arjessa selviytymisen vahvistamisesta. Voidaan siis olettaa, että toimintakykyluokitusta on täydennetty sosiokognitiivisella viitekehyksellä ja että yksi tavoite on omatoimisen kuntoutumisen mahdollistaminen. Teemoihin kuuluu myös tiedon tarjoaminen kuntoutuksesta, sosiaaliturvasta, liiton palveluista ja yhdistystoiminnasta. Lisäksi sisältöihin vaikuttavat kohderyhmältä saadut kurssipalautteet (6 kuukautta kurssin jälkeen) ja toiveet. Validoituja toimintakyky- tai elämänlaatumittareita ei Parkinsonliiton kuntoutuskursseilla käytetä. Kuntoutustoiminta tapahtuu pääosin ryhmissä tai pienryhmissä; läheisille on usein järjestetty toimintaa omassa ryhmässä. Vaikka kurssiohjelmaan ei sisälly yksilöllistä ohjausta, kaikki edellä todettu kertoo asiakaskeskeisyydestä organisaatio-, ryhmä- ja yksilötasolla. Tätä oletusta vahvistaa moniammatillinen lähestymistapa: kurssitoimintaan voivat osallistua kurssin tarpeiden, kurssiteeman ja kohderyhmän mukaan neurologi, psykologi, sosiaalityöntekijä, sairaanhoitaja, fysioterapeutti, puheterapeutti, toimintaterapeutti, vertainen, järjestösuunnittelija, musiikkiterapeutti, liikunnanohjaaja ja ravitsemusterapeutti ja aina kuntoutussuunnittelija sekä tarpeen mukaan avustavaa henkilöstöä. Parkinsonliiton kuntoutuskurssit vaikuttavat pohjautuvan eurooppalaisiin kuntoutussuosituksiin ja niiden kaikkiin osa-alueisiin. Parkinsonliitto on myös ainoa toimija,joka tarjoaa etäkuntoutuskursseja.
Edellä mainittujen lisäksi Parkinsonin tautia sairastaville on tarjolla lääkinnällisenä kuntoutuksena avoterapiaa, joka perustuu terveydenhuoltolain (2010) pykälään 29, joka velvoittaa kunnan potilaan työ- ja toimintakyvyn sekä kuntoutustarpeen arviointiin ja kuntoutussuunnitelman laatimiseen. Tyypillisimmin Parkinsonia sairastava tarvitsee avoterapiana fysio-, toiminta-, puhe- tai ravitsemusterapiaa sekä psykologin tai neuropsykologin palveluja. Avoterapiapalveluita tarjoavat julkinen sosiaalija terveydenhuolto sekä Kela. Kunnat järjestävät lääkinnällisen kuntoutuksen muut terapiat lukuun ottamatta Kansaneläkelaitoksen kuntoutusetuuksista ja kuntoutusrahaetuuksista annetun lain (2015) perusteella Kelan järjestämiä terapioita sekä tapaturma-/potilasvahinko- ja liikennevakuutuslaitosten kustantamia terapioita. Kunnat tuottavat palvelut itse tai ostopalveluna. Osa terapioista, varsinkin fysioterapia, toteutetaan ryhmässä tai yksilöllisesti tai näiden yhdistelmänä. Avoterapiassa voi olla myös kotikäytänteitä. Esimerkiksi Kelan kustantamana terapia voi tapahtua kokonaan tai osittain kotona, mutta julkisen sektorin avokuntoutuspalveluissa toteutus riippuu paljolti resursseista.

\section{Yhteenveto}

Kuntoutuskäytäntöjen yhteenvetona voidaan todeta, että Suomessa Parkinsonin taudin kuntoutus vaikuttaa olevan tutkimusnäyttöön perustuvaa ja moniammatillista (Petri 2010; Brewster ym. 2019), eli kuntoutujan saaman tiedon ja ohjauksen voidaan olettaa olevan sisällöltään asianmukaista. Kuntoutus vaikuttaa olevan suurelta osin asiakaskeskeistä joko organisaatio-, ryhmä- tai yksilötasoilla (Suhonen 2018; Jokstad ym. 2019; Lemetti ym. 2019) mukaanlukien kuntoutujan läheisen (Keus ym. 2020) mutta ei aina holistista. Kuntoutustarjonnassa ei aina huomioida kuntoutujan erilaisia mutta yhtäaikaisia toiminnanvajauk- 
sia ja niiden vaikutuksia toisiinsa. Siinä ei aina huomioida myöskään kuntoutujan sosiokognitiivista viitekehystä (Järvikoski ym. 2015) eli henkilökohtaisia intressejä ja motivaatiota tai sitä, millaiset mahdollisuudet hänellä on vaikuttaa toimintakykyynsä ja kuntoutumiseensa omassa arjessaan. Tämä saattaa johtua siitä, että osalla kuntoutujista ei ole kuntoutussuunnitelmaa, eikä heidän hoidostaan ole kokonaiskuvaa eikä -vastuuta erikoissairaanhoidossa tai perusterveydenhuollossa. Osalta Parkinsonia sairastavilta kuntoutussuunnitelman puuttuminen saattaa estää pääsyn avo- tai laitoskuntoutukseen, jolloin kuntoutumisen etenemisen seuranta ja arviointi on mahdotonta, samoin omatoimisen kotikuntoutumisen turvallinen oppiminen.

Kuntoutus näyttää kohdistuvan fyysisen toimintakyvyn säilyttämiseen ja edistämiseen (kävelykyky, tasapaino, kaatumisen ehkäiseminen ja puhe- sekä nielemismotoriikka), mikä on tärkeää riippumattomuuden ja arkielämän toimivuuden mahdollistamiseksi. Mikäli kuntoutus painottuu tiedon jakamiseen, saattaa toistojen ja riittävän intensiivisen harjoittelun määrätietoisuus jäädä riittämättömäksi, sillä ne edellyttävät yksilöllisen lähtö- ja tavoitetason määrittämistä sekä yksilöllistä ohjausta ja palautetta turvallisen kotikuntoutumisen mahdollistamiseksi. Kaikessa kuntoutustarjonnassa ei kuitenkaan käytetä validoituja mittareita toimintakyvyn mittaamisessa ja tulosten arvioinnissa. Vaikka kuntoutujaa pyritään kannustamaan aktiiviseen fyysiseen harjoitteluun, tiedetään, että usein kotiharjoittelu lopetetaan epämiellyttävien kehontuntemusten ilmaannuttua (Vaartio-Rajalin ym. 2020). Tämä saattaa johtua esimerkiksi kivusta, jonka etiologia Parkinsonin taudissa on moninainen. Kivun hoidossa on tärkeää keskittyä kivun syntymekanismeihin ja noudattaa kivunhoidon yleisiä periaatteita. (Keus ym. 2014.) Kuntoutustarjonnassa kivusta tulisi keskustella nykyistä enemmän ja muistaa perustella kuntoutujalle kivun syntymekanismit esimerkiksi tuki- ja liikuntaelimissä, jos kyseessä on parkinsonismille tyypillinen ryhtimuutos. Yksilöllinen harjoitteluohjaus tai avoterapia, joissa on mahdollisuus lähtötason määritykseen ja progressiiviseen harjoittelun etenemiseen, olisivat parhaat keinot yhdistää intensiivistä ja riittävän kuormittavaa fyysistä harjoittelua sekä harjoitteiden turvallista oppimista.

Myös muuta kuin fyysisen toimintakyvyn edistämiseen tähtäävää kuntoutusta tarvitaan, sillä Parkinsonin taudissa voi ilmetä heikkenemistä kognitiivisissa toiminnoissa, kuten työmuistissa, huomiokyvyssä, ongelmanratkaisussa, useamman yhtäaikaisen tehtävän suorittamisessa, mielialassa ja sosiaalisessa vuorovaikutuksessa. Tarjolla olevissa kuntoutuspalveluissa huomioidaan pääsääntöisesti oppimiseen, kognitioon ja strategiatoimintoihin liittyvät harjoitteet. Kuntoutujan tarpeiden ja mahdollisuuksien tunnistaminen dual-task -harjoitteissa eli motoristen ja kognitiivisten valmiuksien harjoittamisessa vaatii kuitenkin hyvää asiakastuntemusta. Normaalissa kurssimuotoisessa kuntoutuksessa ei välttämättä ole riittävästi aikaa huomioida tilanteita kuntoutujakohtaisesti tai toisaalta työstää tehokkaita dual-task -harjoitteita. Myös psykososiaalinen kuntoutus näyttää sisältyvän kuntoutustarjontaan, sillä hoitopoluissa ja kurssisisällöissä mainitaan elämänlaadun parantaminen, vertaistuki ja moniammatillisiin tiimeihin sisältyvät psykologi ja sosionomi sekä kuntoutujan kotipaikkakuntaan suuntautuva verkostotyö. Toisaalta vain Kelan kuntoutuskurssiin sisältyvät elämänlaatu- ja depressiomittarit eli kuntoutumisen seuranta näiltä osin. Yksilöllinen harjoitteluohjaus tai avoterapia olisivat myös kognitiivisessa ja psykososiaalisessa kuntoutumisessa todennäköisesti toimivimmat vaihtoehdot tavoitteiden asettamiseen, harjoitteiden oppimiseen ja kuntoutustulosten arvioimiseen.

Tutkimustiedon perusteella (Keus ym. 2014; Käypä hoito -suositus 2019; Vaartio-Rajalin ym. 2019; Vaartio-Rajalin ym. 2020) kuntoutusharjoitteita tulisi toteuttaa tutussa arkiympäristössä, kun harjoitellaan siellä ilmeneviä arjen haasteita, arvioidaan Parkinsonia sairasta- 
van kuntoutusstrategioiden toimivuutta tai halutaan turvallisuussyistä osallistaa kuntoutujan läheinen mukaan kuntoutukseen. Nykyisessä kuntoutusjärjestelmässä kotiin suunnattuja palveluja on vielä rajallisesti. Vaikka lähes kaikki tässä analyysissä käsitellyt kuntoutuksen järjestäjät pyrkivät omatoimisen kuntoutumisen edistämiseen kuntoutujan arjessa ja kotioloissa, ne eivät mahdollista yksittäisten harjoitteiden turvallista suorittamista kotioloissa, vaan pyrkimyksenä on lähinnä saada kuntoutujat tietoiseksi mahdollisuuksista. Etäkuntoutusta ja erilaisia kotiin tuotettavia kuntoutus- ja terveyspalvelusovelluksia koskeva tutkimusnäyttö on lupaavaa (mm. Keus ym. 2014; VaartioRajalin ym. 2019), mutta selkeitä suosituksia niiden käytöstä Parkinsonin taudissa ei vielä ole. Parkinsonliiton kurssitoiminta on osittain verkkokuntoutusta tai etäyhteyksien kautta tapahtuvaa ryhmätoimintaa, osin suunnitellusti ja osin covid-19-pandemian seurauksena. Myös avoterapiassa fysio-, toiminta-, puhe- ja ravitsemusterapiaa sekä psykologin ja neuropsykologin palvelua on voinut pandemian aikana toteuttaa etäkuntoutuksena, jos se on soveltunut kuntoutujalle. Koti- ja etäkuntoutuksen sekä erilaisten digipalvelujen kehittämisen tarve on viimeistään nyt ilmeinen.

Koska Parkinsonin tauti on oireiltaan ja etenemiseltään hyvin yksilöllinen, tulisi kuntoutuksessa huomoida kuntoutujan päivittäiset, sairauteen kuuluvat liikkumiskyvyn äkilliset on-off-vaihtelut, henkisen suorituskyvyn heikkeneminen, kivut, väsymys ja muut mahdolliset harjoitteiden kontraindikaatiot. Tueksi tähän tulisi kehittää asiakaskeskeisiä lyhyitä ja helposti hyödynnettäviä PROM-arviointilomakkeita (Patient Recorded Outcome Measures) eli toimintakykyyn, elämänlaatuun ja terveyteen liittyvään elämänlaatuun kohdistuvia mittareita (Murphy ym. 2018), joiden avulla koti-, etä- ja muun kuntoutuksen intensiteettiä voisi suunnitella sekä arvioida oikea-aikaisesti. Osa
Kelan kuntoutuksissa käytettävistä mittareista soveltuu väestömittareiksi, mutta ne eivät välttämättä tuo yksittäiselle kuntoutujalle tai kuntoutustyöntekijälle tarkkaa palautetta yksilötason kuntoutumisesta. Myöskään kuntoutuskurssien hyödyn arviointia ei kerätä systemaattisesti. Palveluntuottaja tekee vain arvion siitä, miten hyödyllinen kuntoutus on heidän mielestään ollut kuntoutujalle ja miten oikea-aikaisesti hän on ollut kuntoutuskurssilla ajatellen toimintakykyä ja mahdollista työ- tai opiskelukykyä. Kuntoutuksen tarjoajien käyttöön tulisi kehittää ja validoida yhtenäinen kuntoutuksen arviointimittari, jotta kuntoutustarjontaa ja kuntoutuksen tuloksia voitaisiin arvioida ja vertailla kansallisesti sekä esimerkiksi suhteuttaa terveystalousanalyyseihin. Lisäksi kuntoutujan kokonaistilanne tulisi arvioida vähintään vuoden välein ja linkittää siihen kuntoutujan kannalta oleelliset toimijat, kuten työterveyshuolto ja moniammatillinen kuntoutustyöryhmä (Käypä hoito -suositus 2019). Koska Parkinson on etenevä sairaus, on tärkeää tehdä kuntoutujan kanssa suunnitelmaa eteenpäin ja sopia, miten muuttuvassa tilanteessa voidaan toimia ja millaisia tukitoimia ehkä tarvitaan (Keus ym. 2014). Terveydenhuollon hoitopolkuja tulee kehittää ja luoda valtakunnallisesti yhtenevät hoitopolut Parkinsonin taudin diagnosoinnista aina palliatiiviseen hoitoon saakka. Hoitopolkujen kehittäminen on erittäin tärkeää, jotta kuntoutuminen mahdollistuisi oikea-aikaisesti, oikeassa määrin ja oikeaan ympäristöön kohdennettuna.

\section{Yhteydenotto:}

Heli Vaartio-Rajalin, Gerontologisen hoidon apulaisprofessori, dosentti

Terveystieteiden yksikkö

Åbo Akademi

heli.vaartio-rajalin@abo.fi 


\section{Kirjallisuus}

Beck AT, Ward CH, Mendelson M, Mock J, Erbaugh J. An inventory for measuring depression. Arch Gen Psychiatry 1961;4:561-71.

https://doi.org/10.1001/ archpsyc.1961.01710120031004

Brewster A, Yuan C, Tan A, Tangoren C, Curry L. Collaboration in health care and social service networks for older adults: association with health care utilization measures. Med Care 2019;57(5):327-33. https://doi.org/10.1097/mlr.0000000000001097

Jokstad K, Skovdahl K, Landmark B, Haukelien H. Ideal and reality; Community healthcare professionals' experiences if user-involvement in reablement. Health Soc Care Community 2019;27:907-16.

https://doi.org/10.1111/hsc.12708

Järvikoski A, Härkäpää K, Salminen AL. 2015. Kuntoutuksen teorioista ja ICF-mallista. Kuntoutus 2/2015:18-32.

Kalf JG, de Swart BJM, Bonnier M, Hofman M, Kanters J, Kocken J ym. Guidelines for speech-language therapy in Parkinson's disease. Nijmegen, The Netherlands / Miami (FL), U.S.A: ParkinsonNet/NPF, 2011.

Kansaneläkelaitos. Liikehäiriösairauksien kuntoutuskurssi, Kelan kuntoutuksen palvelukuvaus, harkinnanvarainen ja vaativa lääkinnällinen kuntoutus. Kela, 2020. Internet: https://www.kela. fi/documents/10180/31513377/Liikehairiosairaudet_palvelukuvaus_2021.pdf/babf968b-efae4490-99bc-bbd6e65f4748 (viitattu 20.10.2020).

Keus SHJ, Munneke M, Graziano M, Paltamaa J, Pelosin E, Domingos J ym. European Physiotherapy Guideline for Parkinson's disease. KNGF/Parkinson Net, the Netherlands, 2014.

Käypä hoito -suositus. Parkinsonin tauti. Suomalaisen Lääkäriseuran Duodecimin ja Suomen Neurologisen Yhdistyksen asettama työryhmä. Helsinki: Suomalainen Lääkäriseura Duodecim, 2019. Internet: https://www.kaypahoito.fi/ hoi50042 (viitattu 20.10.2020).

Laki Kansaneläkelaitoksen kuntoutusetuuksista ja kuntoutusrahaetuuksista annetun lain muuttamisesta 145/2015.

Lemetti T, Voutilainen P, Stolt M, Eloranta S, Suhonen R. Older patient's experiences of nurse-tonurse collaboration between hospital and primary health care in the care chain for older people.
Scand J Caring Sci 2019;33(3):600-8. https://doi.org/10.1111/scs.12653

Mathias S, Nayak USL, Isaacs B. 1986. Balance in elderly patients: the "Get-up and Go" test. Arch Phys Med Rehabil 1986;67(6):387-9.

Murphy M, Hollinghurst S, Salisbury C. Identification, description and appraisal of generic PROMs for primary care: a systematic review. BMC Fam Pract 2018;19:e41. https://doi.org/10.1186/s12875-018-0722-9

Petri L. Concept analysis of interdisciplinary collaboration. Nurs Forum 2010;45(2):73-82. https:// doi.org/10.1111/j.1744-6198.2010.00167.x

Scobbie L, Dixon D. Theory-based approach to goal setting. In: Siegert RJ, Levack WMM, ed. Rehabilitation goal setting: theory, practice and evidence. Boca Raton: CRC, 213-36.

Sosiaali- ja terveysministeriö. Kuntoutuksen uudistamisen toimintasuunnitelma vuosille 2020-2022. Sosiaali- ja terveysministeriön raportteja ja muistioita, 2020:39. Helsinki.

Sturkenboom IHWM, Thijssen MCE, Gons-van Elsacker JJ, Jansen IJH, Maasdam A, Schulten M ym. Guidelines for occupational therapy in Parkinson's disease rehabilitation. Nijmegen, The Netherlands / Miami (FL), U.S.A: ParkinsonNet/NPF, 2011.

Suhonen R. Asiakaskeskeisyys, arvot ja ikääntyneiden ihmisten sote-palvelut. 2018. Internet: https://blogit.utu.fi/utu/2018/04/20/asiakaskeskeisyys-arvot-ja-ikaantyneiden-ihmisten-sote-palvelut/ (viitattu 12.2.2021).

Suomen Parkinsonliitto. 2018. Internet: https://www. parkinson.fi/pa-svenska (viitattu 8.22021 ).

Terveydenhuoltolaki 30.12.2010/1326.

Terveysportti. GAS-menetelmä. Internet: https://www.terveysportti.fi/dtk/tmi/koti (viitattu 11.12.2020).

Vaartio-Rajalin H, Mattjus C, Nordblad J, Fagerström L. Developing person-centered, interactive, systematic, effective rehabilitation (PISER) for persons with Parkinson's - the outcomes of a pilot intervention. Neurophysio and Rehab 2020;3:17. https://doi.org/10.33805/2641-8991.124

Vaartio-Rajalin H, Rauhala A, Fagerström L. Person-centered home-based rehabilitation for persons with Parkinson's disease - a scoping review. Int J Nurs Stud 2019;99. https://doi.org/10.1016/j.ijnurstu.2019.103395 
van Asseldonk MJMD, Dicke HC, van den Beemt BJW, van den Berg DJ, Ter Borg S, Duin GM ym. Dietetic guideline for Parkinson's disease. The Hague: Lemma Publisher, 2012.

World Health Organization. Programme on mental health: WHOQOL user manual. WHO, 1998. Internet: https://apps.who.int/iris/bitstream/ handle/10665/77932/WHO_HIS_HSI_ Rev.2012.03_eng.pdf;jsessionid=AEFDA3F399E351AFB61CC9D82140E30F?sequen$\mathrm{ce}=1$ (viitattu 11.12.2020).
World Health Organization. International Classification of Functioning. Disability and Health: ICF. WHO, 2001. Suomennos: Toimintakyvyn, toimintarajoitteiden ja terveyden kansainvälinen luokitus. Sosiaali- ja terveysalan tutkimus- ja kehittämiskeskus Stakes, Ohjeita ja luokituksia 2004:4. 